\title{
United States-Mexico Border Diabetes Prevalence Survey: lessons learned from implementation of the project
}

\author{
Federico G. de Cosío, ${ }^{1}$ Beatriz A. Díaz-Apodaca, ${ }^{2}$ \\ Rosalba Ruiz-Holguín, ${ }^{3}$ Agustín Lara, ${ }^{4}$ and Carlos Castillo-Salgado ${ }^{1}$
}

Suggested citation de Cosío FG, Díaz-Apodaca BA, Ruiz-Holguín R, Lara A, Castillo-Salgado C. United States-Mexico Border Diabetes Prevalence Survey: lessons learned from implementation of the project. Rev Panam Salud Publica. 2010;28(3):151-8.

ABSTRACT This paper reviews and discusses the main procedures and policies that need to be followed when designing and implementing a binational survey such as the United States of America (U.S.)-Mexico Border Diabetes Prevalence Study that took place between 2001 and 2002. The main objective of the survey was to determine the prevalence of diabetes in the population 18 years of age or older along U.S.-Mexico border counties and municipalities. Several political, administrative, financial, legal, and cultural issues were identified as critical factors that need to be considered when developing and implementing similar binational projects. The lack of understanding of public health practices, implementation of existing policies, legislation, and management procedures in Mexico and the United States may delay or cancel binational research, affecting the working relation of both countries. Many challenges were identified: multiagency/multifunding, ethical/budget clearances, project management, administrative procedures, laboratory procedures, cultural issues, and project communications. Binational projects are complex; they require coordination between agencies and institutions at federal, state, and local levels and between countries and need a political, administrative, bureaucratic, cultural, and language balance. Binational agencies and staff should coordinate these projects for successful implementation.

Key words Border health; international cooperation; diabetes mellitus, type 2; Hispanic; United States; Mexico.

This paper reviews and discusses the main procedures and policies that need to be followed when designing and implementing a binational survey such as

\footnotetext{
1 Pan American Health Organization, Washington, D.C., United States of America. Send correspondence to Federico G. de Cosío, decosige@paho.org

2 Institute of Biomedical Sciences, Autonomous University of Ciudad Juarez, Juarez, Chihuahua, Mexico.

3 U.S.-Mexico Border Diabetes Prevalence Study, Pan American Health Organization, El Paso, Texas, United States of America.

4 Adult and the Elderly Health Program, Ministry of Health of the State of Colima, Mexico.
}

the U.S.-Mexico Border Diabetes Prevalence Study that took place between 2001 and 2002. The main objective of the survey was to determine the prevalence of diabetes in the population 18 years of age or older along U.S.-Mexico border counties and municipalities. Several recommendations are made to guide researchers in developing future binational projects.

As described by Diaz-Kenney et al. (1), for public health purposes, the border is seen as a single geographic and epidemiologic unit as disease "knows no bor- ders." From the point of view of the United States and Mexico federal governments, the border is viewed as separate countries where any type of binational collaboration needs to be coordinated in Mexico City and Washington, D.C., which are miles from the border. Communities along the U.S.-Mexico border perceive that border public health problems should be addressed with a binational perspective at the border. With this idea in mind, the origin of the concept of one geographic and epidemiologic unit used in this study is shaped (2). 
It is important to have a basic understanding of the legal and cultural issues on each side of the border as well as the difference in healthcare delivery systems, data collection and dissemination, information sharing, definition and meaning of public health problems (i.e., the hemoglobin A1c cut point in the United States is $7.0 \%$ and in Mexico it is $6.5 \%$ ), and methods and practices for approaching the same problem on each side of the border. This understanding of the border may help prevent delays and frustration during design, implementation, and analysis of data collected with a binational scope. Existing information on how to design and carry out a binational survey is scarce and limited to mostly anecdotal descriptions from border researchers (3).

In preparing the U.S.-Mexico border diabetes prevalence survey, most of the topics mentioned earlier were considered. Cultural issues involving people from the Mexican side, Hispanic people on the U.S. side (mainly of Mexican origin), and the non-Hispanic population; language; and formal and informal networks are important factors that can influence the final results of a binational survey.

\section{GLOBAL HEALTH AND EPIDEMIOLOGIC TRANS-BORDER PROBLEMS AT THE LOCAL LEVEL}

Communities on both sides of the U.S.-Mexico border share a geographic and socioeconomic space separated by a geopolitical line, or a river, called the border. Therefore, to improve the health of these border communities, it is necessary to coordinate activities that have a binational impact along the border.

Although each side of the border has its own political and administrative procedures, the population dynamics are interdependent (driven by commerce, school, sports, work, access to healthcare, medicines, visiting family and friends, and much more). These interactions may take place in any of the languages spoken in the community-English, Spanish, and sometimes a mix of English and Spanish called Spanglish (mainly spoken on the U.S. side). The perceived possibility of employment with improved socioeconomic living conditions along the border has resulted in high levels of migration to this area, with an urbanization process characterized by large numbers of poverty belts, called colonias on the U.S. side and marginal zones on the Mexican side.

The interdependence of both sides on each other has strengthened the popular concept of "disease knows no borders" and that is why health issues should be addressed through collaborative and coordinated joint efforts.

In order to address border health problems of binational interest, it is necessary to recognize the need for a vision of trans-border work in which both countries accept that the border is an epidemiologic unit; thus, health problems should be addressed on both sides of the border with coordinated strategies.

With the above in mind, it was possible for the Pan American Health Organization/World Health Organization (PAHO/WHO) U.S.-Mexico Border Office to develop the health profiles of the border communities (4). The health profiles presented information on core health indicators, including the main causes of death and characteristics of the population for each of the 12 main border communities called sister cities. Sister cities are linked economically, culturally, and environmentally and are separated by the border. Throughout the years, the health profiles showed diabetes as a leading border health problem. In March 2001, the U.S.-Mexico Border Health Commission established the binational health agenda of health promotion and disease prevention (5). This health agenda, known as Healthy Border 2010, served as the basis for developing bilateral border-wide health promotion and disease prevention projects in the border region. Nearly onequarter of the objectives were established as developmental because no measurable data were available. Diabetes was identified as 1 of 11 topic areas for both sides of the border without realistic measurable objectives: Mexico, reduce deaths due to diabetes by $10 \%$ and keep the hospitalization rate stable; United States, reduce deaths due to diabetes by $10 \%$ and reduce hospitalization by $25 \%$ (5).

As a result of the need to address the diabetes problem on both sides of the border with a binational perspective, it was necessary to create a baseline by identifying the real prevalence of diabetes and its main risk factors. Therefore, a protocol to conduct a diabetes prevalence survey was developed in order to generate binational data. This process is known as the U.S.-Mexico Border Diabetes Prevalence Survey.

The U.S.-Mexico Border Diabetes Prevalence Survey was conceived not as academic research but as an identified need that emerged from the border community and the active involvement of civil society. It brought to the attention of federal and state governments on both sides of the border the need to determine the real prevalence of diabetes and the main risk factors associated with the disease. Border public health officials and partners and all those involved believed that a binational project could help prevent and control diabetes on the border.

Planning of the study began with full involvement of the border health community and civil society, including two main project supporters: the El Paso del Norte Health Foundation and the California Endowment. A key factor in obtaining the participation and political support of federal and state governments was that the survey has a grass roots origin, a factor that brought a higher level of credibility to obtain funding. This type of experience remains as the only one with this scope of participation and collaboration from both countries. The importance of this study relies on the concept of working together. Therefore, health authorities, civil society, academia, and the community at large coordinated efforts and established binational mechanisms of collaboration to address a global health problem from a local perspective.

In planning this study, several binational meetings were conducted on both sides of the border. The U.S. Centers for Disease Control and Prevention (CDC) provided seed money through a grant to the U.S.-Mexico Border Health Association to explore the interest of the border community to conduct a diabetes prevalence study simultaneously on both sides of the border and to initiate the process for developing the survey protocol, questionnaire, and operational procedures through a consensus process.

It was not easy to bring together representatives from both countries and both sides of the border; however, it was shown that "when there is a will, there is a way." The opportunities this study has brought to light are measured not only 
by the results of the survey but also by the opportunities that emerged to develop and implement future binational health collaborations.

\section{OVERVIEW OF U.S.-MEXICO BORDER DIABETES SURVEY}

In any type of survey along the U.S.-Mexico border, in which binational collaboration is required, it is important to have in mind that each side of the border has its own organization of healthcare delivery systems and laws that may affect working relations (6) between Mexico and the United States. Each state has certain levels of autonomy to make decisions pertaining to its own state. The degree of political support to binational activities may vary from state to state and from one side of the border to the other. In addition, each municipality and county along the border may have its own health political agenda that in some cases does not coincide with the state agenda. This situation is more evident when the municipal or county government is from a different political party than the state government, as is the case in Mexico.

By law, when federal funds are awarded to a given agency in the United States, without clearance from the Department of State it is not possible to use those resources in a foreign country. To obtain clearance, a federal agency has to demonstrate how the problem can affect the United States. This process is timeconsuming and, in some instances, the implementation of activities is delayed as was the case in this study.

\section{PROCESS FOR WORKING IN A TRULY BINATIONAL CONTEXT}

Most processes addressed in this binational survey were related to issues associated with differences in administrative, management, and implementation procedures. Improper handling of these procedures could result in conflict and frustration between participating agencies.

During the study several challenges were identified, and they are presented as part of the analysis of the lessons learned from this binational survey. They are related to: 1) multiagency and multifunding coordination, 2) ethical and budget clearances, 3) project management, 4) administrative procedures, 5) laboratory procedures, 6) cultural is- sues, and 7) project communication (Table 1).

\section{Multiagency and multifunding coordination}

The U.S.-Mexico Border Diabetes Prevalence Study was a multifunded, multiagency project with more than 150 agencies participating (7). The main agencies that participated in coordinating and implementing the survey were PAHO, the U.S.-Mexico Border Health Association, the CDC, the Mexican ministry of health, state health authorities and diabetes control programs of the 10 border states (Arizona, California, New Mexico, and Texas on the U.S. side and Baja California, Chihuahua, Coahuila, Nuevo Leon, Sonora, and Tamaulipas on the Mexican side), the Paso del Norte Health Foundation, and the California Endowment.

In the early stages of this study, this multifunded/multiagency characteristic was considered one of the main strengths; however, because of the involvement of many agencies in the different phases of the study, it was difficult to comply with the technical and administrative procedures and requirements of each funding agency. Each agency had different conditions on how to use and not use the funds provided for the study. For example, in the United States, the California Endowment, which provided funds for the California study, conditioned the use of its resources only to the state of California, while the El Paso del Norte Health Foundation financial resources were allowed to be used only in El Paso, Texas, and Las Cruces, New Mexico, both in the United States, and in Juarez, Chihuahua, Mexico. The Texas Department of Health provided some funding for the study, mostly in the southeast border part of the state, but, as in the previous cases, these resources could be used only in selected areas in Texas. The funding provided by the CDC was used to complement the study in areas where no other funds were available. All financial resources were earmarked and were used only for the specified purposes for which they were given. Therefore, in order to carry out the activities of this study, it was necessary to consider the geographic area, the activity, and the requirements of each funding agency. Therefore, several accounting reports (one for each funding agency) were systematically prepared.

Resources from the Mexican side were mostly in-kind contributions. These contributions were provided by the three levels of government (federal, state, and local) and by the Diabetes Association of the State of Sonora. All these resources were limited to a specific area, as was the case in the United States. The contributions consisted of staff time for supervision, interviewers, phlebotomists, laboratory analysis, and some administrative and logistic support.

There were also differences in the ways the study was administrated on each side of the border. Whereas on the Mexican side most activities were coordinated by the Mexican ministry of health through the six state health departments, the U.S. side had different implementation models and participants. Each model depended on the funding source and the agency contracted to undertake the survey activities. For instance, in Texas there were different types of contractors (one in the lower valley, one in the El Paso del Norte area, and one in the Laredo-McAllen area); there was one contractor in Arizona and there were two in New Mexico. On the Mexican side, PAHO became the funding agency for each of the survey sites; however, the federal ministry of health coordinated the use of funds. PAHO had to take into consideration the CDC's contract specifications to execute all the financial resources on either side of the border.

\section{Ethical and budget clearances}

When a study involves human subjects, such as this one, for international agreements it is necessary to submit project protocols for an ethical and human rights review in order to ensure that no physical or mental harm will be caused to any person participating in the study. On the U.S. side, it was necessary to obtain an institutional review board (IRB) approval. In the case of Mexico, it was necessary to obtain the federal ethical certification that stipulated that the project met Mexican research ethical and scientific standards. These approvals were needed in order to obtain clearance from the CDC to use federal funds. The process to obtain these permits or approvals has many 
TABLE 1. Process for working in a binational context, United States-Mexico, 2001-2002

\begin{tabular}{|c|c|c|c|}
\hline Challenge & Process & Agencies & Description of process \\
\hline \multirow{2}{*}{$\begin{array}{l}\text { Multiagency and } \\
\text { multifunding } \\
\text { coordination }\end{array}$} & Multiagency & $\begin{array}{l}\text { More than } 150 \text { organizations participated } \\
\text { in the project. }\end{array}$ & $\begin{array}{l}\text { Government, academic, and non-government agencies and } \\
\text { institutions participated in all phases of the project. }\end{array}$ \\
\hline & Multifunded & $\begin{array}{l}\text { PAHO, a El Paso del Norte Health } \\
\text { Foundation, California Endowment, } \\
\text { U.S.-Mexico Border Health Association, } \\
\text { Project Concern International (Border } \\
\text { Health Initiative). }\end{array}$ & $\begin{array}{l}\text { Each organization has procedures and conditions for use of its } \\
\text { funds. Financial and implementation reporting must meet each } \\
\text { agency's specifications. }\end{array}$ \\
\hline $\begin{array}{l}\text { Ethical and budget } \\
\text { clearances }\end{array}$ & $\begin{array}{l}\text { Ethical requirements } \\
\text { U.S. federal funds } \\
\text { clearances }\end{array}$ & $\begin{array}{l}\text { IRB, }{ }^{b} \text { U.S. state IRBs, university IRBs, } \\
\text { Mexican code of ethics } \\
\text { Department of State and Office of } \\
\text { Management and Budget }\end{array}$ & $\begin{array}{l}\text { IRB and ethical clearance at the federal and state levels was } \\
\text { required. Each process has its own rules. } \\
\text { Clearance from Department of State is required before U.S. funds } \\
\text { are used in a foreign country. To get this clearance, Office of } \\
\text { Management and Budget and IRB need to give approval. }\end{array}$ \\
\hline \multirow[t]{2}{*}{ Project management } & Coordination & $\begin{array}{l}\mathrm{PAHO} / \mathrm{WHO} \mathrm{C}^{\mathrm{C}} \text { U.S.-Mexico Border Office } \\
\text { in coordination with the steering committee }\end{array}$ & $\begin{array}{l}\text { PAHO was in charge of the day-to-day project operation. There } \\
\text { was a binational coordinator for overall project implementation } \\
\text { and there was a Mexican and a U.S. coordinator. }\end{array}$ \\
\hline & Partner coordination & $\begin{array}{l}\text { Partner coordination was achieved through } \\
\text { a steering committee. } \\
\text { The Project Concern International (funded } \\
\text { by California Endowment) was responsible } \\
\text { for managing resources in California. } \\
\text { Contracts were established for project } \\
\text { implementation in each U.S. site to carry } \\
\text { out survey. }\end{array}$ & $\begin{array}{l}\text { This committee was composed of three subcommittees: } \\
\text { executive, technical, and implementation. } \\
\text { Close coordination between PAHO and Border Health Initiative } \\
\text { was established to ensure that survey protocol was followed. } \\
\text { Process was time-consuming and follow-up was difficult. Several } \\
\text { contracts were developed and each has its own specification } \\
\text { (e.g., phlebotomists, interviewers, blood analysis). }\end{array}$ \\
\hline
\end{tabular}

Develop and apply Purchased and distributed in each survey questionnaires, buy site by PAHO. and distribute equipment.

\section{Administrative procedures}

\section{Laboratory procedures}

Contracts for interviewers

Payroll for interviewers

Blood collection

Blood handling

Blood analysis

Meaning of work

Socioeconomic status

Project communication Language
PAHO/WHO U.S.-Mexico Border Office

PAHO/WHO U.S.-Mexico Border Office

PAHO/WHO U.S.-Mexico Border Office

Certified phlebotomists were hired in the United States; in Mexico certified or auxiliary nurses were in charge of the process.

Blood was stored at a selected clinic on both sides of the border at $<20^{\circ} \mathrm{C}$ before it was shipped for analysis either to the University of Kansas or to the Nuevo Leon State Laboratory.

U.S. and Mexican laboratories coordinated efforts to analyze blood and do quality analyses.

Different cultural values and languages

Participants in the United States were mainly low and middle income. In Mexico, they were from all socioeconomic classes.

English and Spanish
To cross equipment to the Mexican site, it was necessary to contract the services of a custom broker.

Financial resources were transferred to the Mexican ministry of health to carry out survey activities as stated in protocol.

To expedite the process, PAHO directly contracted interviewers mainly from Ciudad Juarez, Chihuahua, Mexico. Local health departments coordinated and supervised interviewers.

PAHO has to establish a payroll to pay interviewers' salaries. Salaries were paid on a weekly basis in cash.

Contracting phlebotomists was complex in the United States. Each state and county has its regulations. Sometimes it was necessary to obtain insurance for phlebotomists.

Coordination with laboratories was established before blood was shipped to ensure delivery within 48 hours. Each blood-storing laboratory was responsible for shipping blood. If dry ice was not available, arrangements were made to procure it.

Mexican laboratory was equipped with equipment for testing glycosylated hemoglobin A1c donated by Primus and was trained in the use of equipment and analysis of blood.

Hispanics in Mexico speak mainly Spanish; the United States has mix of Hispanics and whites who speak English, Spanish, and Spanglish.

In some wealthy U.S. neighborhoods, residents called the local police department because interviewers looked "too Latino."

All meetings, documents, and communications were in English and Spanish to ensure proper coordination and understanding of project implementation.

a PAHO: Pan American Health Organization.

b IRB: Institutional Review Board.

c WHO: World Health Organization. 
requirements and can take up to 1 year, particularly in the United States where review of the survey's protocol and consent letter were included. The U.S. federal government required the study to have the Mexican ethical certification before the U.S. IRB could be approved.

Once the Mexican federal ethical certification and the U.S. IRB approvals were granted, it was necessary to apply for a U.S. state IRB. The process differed in each border state. For example, the state of California accepted the U.S. federal IRB. The states of Texas and Arizona have a state IRB process that is coordinated by their own departments of health, each with different administrative procedures. Texas required the principal investigator and other key researchers to obtain a state IRB certification. In Arizona this certification was not required. In the state of New Mexico, the IRB approval was granted through the New Mexico University. The New Mexico IRB approval required an academic member of a university to be involved in the study design and implementation. As in the case of the U.S. federal government, each state and university had its own IRB boards that met on predetermined dates. These dates did not necessarily meet the project deadlines; as a consequence, work plans were continuously delayed and reprogrammed. In the case of Mexico, all the Mexican border states accepted the country's federal ethical certification.

Once the U.S. IRB was obtained, it was necessary to proceed with the next process in order to obtain an Office of Management and Budget (OMB) clearance to be able to execute the granted federal funds. This process is required to conduct federally sponsored data collections. The process consists of a statement explaining the purpose of the study, use of data, burden to the respondent completing the questionnaire form, and statistical validity of data collection. Privacy protection of participants was ensured through consent letters approved through this $\mathrm{OMB}$ process. As the IRB approval has a life span of 1 year, if the OMB clearance was not obtained before the expiration date of the IRB, it was necessary to reapply for another IRB review. Without these authorizations, no federal resources could be used and the study could not be initiated.

This cumbersome process of obtaining U.S. federal IRB and OMB approval, including clearance from the U.S. Depart- ment of State, would not have been a problem in regular circumstances; however, given that the project was multiagency funded, with financial resources from several sources (federal and state governments, not-for-profit organizations, and foundations), there was considerable pressure from the stakeholders to start the study. Each participating organization had its own fiscal year and administrative procedures, including pressure from boards to show that donations, contributions, and collaborations were properly used. It was difficult for them to understand this lengthy federal government approval process. They wanted to see the study results.

\section{Project management}

PAHO was charged with coordinating and implementing the study and thus was accountable for its success. However, not all the funds were administered by PAHO. For example, the California Endowment awarded Project Concern International, through its Border Health Initiative, the financial resources to conduct the survey on the California border. These funds were conditioned to be used only for the U.S.-Mexico Border Diabetes Prevalence Study Project. Although these resources were administered by Project Concern International, PAHO was accountable for the study results.

Project implementation was carried out with support of a steering committee composed of executive, scientific, and intervention advisory committees. Committee members were representatives of each of the agencies involved in the survey from Mexico and the United States. Their participation on each committee was mainly related to their expertise and level of support provided to the project. Chairpersons and vice-chairpersons were elected by a simple majority vote and held the position for 1 year. In order to ensure equity, it was decided that the chairperson should be from one country and the vice-chairperson from the other. During the election process, the position rotated to the other country. Together these three committees played an important role in the project's design, implementation, and decision making. Each participating agency and stakeholder (public, not-for-profit, academic, and non-government organizations) involved in implementing the project on either side of the border was represented on the steering committee. The main challenge in this component was to keep a binational balance during the committee's meetings, including overcoming any language barrier that could affect implementation of the study, by providing simultaneous interpretation and translation of documents. Project coordination was charged with ensuring that every participant had the same opportunity to express his or her point of view.

Day-to-day project operations were the responsibility of a binational coordinator, who was supported by two subcoordinators, one for each side of the border. They were responsible for implementing the survey in their respective country. At the request of the Mexican ministry of health, it was decided that all decisions related to implementation of the study on the Mexican side should be channeled through a national coordinator appointed by the ministry of health to ensure a smooth process, as it was believed that through his or her coordination with the Department of Health of each Mexican state the study would be executed according to study protocols.

\section{Administrative procedures}

During implementation of the project, it was decided that the PAHO/WHO U.S.-Mexico Border Office would coordinate all administrative efforts needed to successfully carry out the survey. PAHO's administrative procedures were followed (letters of agreements and contracts for survey implementation and interviewers, purchase orders, administration of resources). This task was not easy to perform because the project was multiagency and multifunded. Several administrative and financial procedures were required to implement the study.

In most cases on the Mexican side, resources were transferred to the Mexican ministry of health at the local level through letters of agreements, which is a standard procedure that PAHO uses to undertake technical cooperation, as stated in the protocol. This process helped strengthen institutional capacity building. However, in some cases PAHO had to directly contract an interviewer's services, as in the case of Ciudad Juarez, Chihuahua, Mexico. Coordination and supervision of activities were the responsibility of the local health department. The main advantage of this option was to keep the project running 
smoothly. On the other hand, the main disadvantage was that the $\mathrm{PAHO} / \mathrm{WHO}$ U.S.-Mexico Border Office has to establish an additional administrative procedure to overcome the burden imposed by the payroll of the short-term staff. Salaries for these persons were paid on a weekly basis in cash.

\section{Laboratory procedures}

As this was a binational study, different laws and regulations applied in each country with reference to human specimen samples. It was not possible to have one laboratory process and analyze all blood samples from both sides of the border. It was necessary to establish agreements with one laboratory in each country. In the United States, the analysis was done by the University of Missouri Diabetes Diagnostic Laboratory; in Mexico, the samples were analyzed by the Nuevo Leon State Laboratory of the State Department of Health. It was necessary to ensure that both laboratories had the same technology and followed the recommended standards to perform fasting glucose and hemoglobin A1c (Hb1Ac) analysis, as stated in the project's operational manual (8). Because the laboratory in the United States had the latest technology for fasting plasma glucose and $\mathrm{HbA1c}$ analysis, it was necessary to bring the laboratory of Nuevo Leon to the same level. Thus, the Mexican laboratory was equipped with the same technology for HbA1c as the U.S. laboratory in order to make their analyses comparable. Primus Corp. from Kansas City, Missouri, donated the equipment, reagents, and materials for $\mathrm{HbA} 1 \mathrm{c}$ blood analysis. Primus Corp. personnel trained laboratory staff in use of the equipment and provided technical support for equipment maintenance during the study at no cost. As the equipment was donated, there was a need to obtain Mexican customs clearance to transfer the equipment to Mexico. The process took more than 6 months before all Mexican custom requirements were met (letter of donation of the equipment, letter of acceptance of the donation from the ministry of health, hiring of a customs broker to cross the equipment to Mexico, and exemption of taxes from the ministry of treasury of Mexico). The project paid all costs incurred to place the equipment in Mexico.

The quality control for fasting plasma glucose and $\mathrm{HbA} 1 \mathrm{c}$ included two procedures. First, $2 \%$ of the samples were ran- domly selected and analyzed, either within assay or between assays. Second, four levels of standard controls covering the full range of plasma glucose concentrations for normal and diabetic samples and $\mathrm{HbA1c}$ were used. The problem encountered in conducting quality controls was related to the exchange of blood samples between the two laboratories. It was necessary to obtain customs clearance and CDC waivers to cross blood samples across the U.S. border to comply with the quality control requirements. This process was done every time quality controls were required. It was time-consuming and depended on administrative and sometimes bureaucratic procedures.

On the Mexican side, blood samples were taken to a public laboratory at each study site; on the U.S. side, selected private laboratories were contracted for collecting blood samples, except in West Texas, where the state laboratory managed the samples. All samples were collected by certified phlebotomists in the United States and by certified or auxiliary nurses in Mexico. For glucose determination, a sample of venous whole blood was collected. Local laboratories were responsible for centrifuging and storing at $-20^{\circ} \mathrm{C}$ all blood specimens at the local level until they were air transported to the central laboratory in each country. To transport these samples to the central laboratory, it was necessary to ship them in a cooler with dry ice to ensure that they were kept at the required temperature. However, dry ice was not always available in every participating community, mostly on the Mexican side of the border. Thus, personnel from the study made arrangements with U.S. communities to ship dry ice across the border. It was necessary to make agreements with the air transport carrier each time blood samples were shipped to the central laboratory to ensure that specimens were delivered within 48 hours after shipment; otherwise, the dry ice effect could be lost and blood samples may no longer be useful for the study. If delivery was not made within that time period, it was necessary to arrange with study participants to draw blood again.

\section{Cultural issues}

To work on the U.S.-Mexico border means working with two different countries with different cultural values and languages. Whereas on the Mexican side, there is more homogeneity in ethnic origin, on the U.S. side the population is a mix of Hispanics, Native Americans, whites, and other races and ethnic groups, including Mexican Americans. This diversity affected the level of participation in the study, mainly on the U.S. side (interviewers in non-Hispanic communities had to request authorization to enter the communities; census tracks that were selected as "Anglo communities" were no longer "Anglo communities"; interviewers were not accepted in certain communities because of their ethnicity). To overcome these obstacles, local community leaders were contacted to obtain their support, and television and radio advertisements in both languages were used to inform potential participants about the survey; pamphlets in English and Spanish were distributed in the selected census tracts to make people aware of the interviews, and communities of faith were involved in the communication process. On the U.S. side, people of Hispanic origin were more willing than whites to participate. On the Mexican side, there were fewer problems related to people's participation in the study as community leaders provided support to contact participants.

It was not unusual for female participants of Hispanic ethnicity to get a husband's or an elder's authorization to participate in the study. The main reason given by female participants to request authorization was that they did not want to have personal problems with their family members, mainly husbands, or because they feared being asked questions related to their immigration status. Every potential participant was informed verbally and through the consent letter that all information collected in the survey would be used only for the purpose of establishing the prevalence of diabetes and that no information with identifiers would be shared with any U.S. government agency. It was common for interviews to be conducted in the presence of a female participant's husband; therefore, interviewers had to arrange to schedule the interviews at a convenient time for both the interviewee and her husband. Although the husband was present, interviewers ensured that only the person selected to be interviewed answered each question.

Difference in socioeconomic status was an important factor in participation in the 
study. On the Mexican side, it was easier to obtain participants of any socioeconomic status; on the U.S. side, most participating individuals were low- or middle-income status. It was not unusual in U.S. middle- and high-income neighborhoods for residents to call the local police department because interviewers looked suspicious or "too Latino."

\section{Project communication}

All materials used or generated for the project, such as the study's proposal, meeting minutes, manuals, training materials, questionnaires, and all information about the study to be developed and distributed, had to be taken into consideration with the multicultural and bilingual characteristics of the border. To keep the project running in both languages and maintain the cultural sensitivity during implementation was a challenge. All communications had to be generated in both languages. Translators and interpreters on both sides of the border were hired to provide project participants and stakeholders with the appropriate means to boost communication. Although this requirement was time-consuming and expensive, it proved to be an excellent option that prevented conflicts and miscommunications between participants from both countries. It also helped smooth the implementation process.

The hiring of bilingual and bicultural project staff helped to deal with cultural, administrative, and bureaucratic issues. Staff knowledge of cultural values and processes on each side of the border was a useful tool to help people on each side of the border to understand what was happening on the other side, thereby preventing conflicts and minimizing frustration.

\section{DISCUSSION}

Although people working on both sides of the border historically have been interested in binational research, the lack of information, knowledge of the systems, and laws that facilitate the processes in each country have been barriers because of their complexity. These barriers may affect working relations between both countries.

Although there have been several attempts to conduct simultaneous binational research along the border, few experiences have been documented. Because of the difficulties encountered and the complexity of the processes, in most cases, border research has remained on one side of the border, inferring what would be the situation on the other side, as mentioned by Homedes and Ugalde (2).

Several administrative, financial, ethical, legal, and technical issues were identified as critical factors that need to be considered when planning and implementing a binational project. Reports describing the challenges faced during development of "truly binational" research are mostly anecdotal. Our experience may help other researchers interested in working in a "truly binational" environment to better plan a study and make its implementation more realistic.

Political correctness and cultural sensitivity are essential in the process and need to be considered before starting any kind of binational collaboration. If they are not considered, chances are that agreement will not be reached on both sides.

We identify major differences in financial and technologic resources on both sides of the border. Whereas the U.S. side is better off in reference to financial and technological resources, the Mexican side provides human resources and infrastructure to carry out binational projects as in-kind collaborations. Also, the availability of technology may influence diagnosis and definitions of public health problems. Although financial resources on the Mexican side are limited, there is a tendency to underestimate Mexican collaboration on binational projects, because most of the time their resources are not monetary but in-kind. This allocation of in-kind resources may have a value equal to or greater than "the monetary contribution. For example in this survey, the laboratory costs for "Mexican border communities and analysis of fasting glucose were in-kind contributions from Mexican federal and state governments.

There is a tendency for people not to express their true feelings because they do not want to hurt the feelings of the other person; the process could be delayed until this situation is clarified and a common understanding is reached.

At times, each side may have different views about the same border health issue. To solve these problems, it is necessary to reach consensus; that process is time-consuming, but once consensus is reached the process will move forward as planned. These differences need to be considered during the planning process.
To overcome all the challenges of working in a binational context described here, it is important to keep in mind that all the personnel working on a binational project must be bilingual and bicultural. Staff working on border health issues should have knowledge of the health, administrative, and political procedures of each country. "Real binational agencies" such as the PAHO/ WHO U.S.-Mexico Border Office, the U.S.-Mexico Border Health Commission, the U.S.-Mexico Binational Health Commission, and the Border Environment Cooperation Commission could provide the expertise needed to support coordination of activities related to border binational projects.

Establishment of a binational steering committee with equal representation from both sides of the border has the advantage of providing guidance in implementation of the study with cultural sensitivity and political knowledge. The committee can keep the communication process open and dynamic and minimize misunderstandings. In addition, the committee may facilitate identification of the main administrative and legal procedures and provide technical and administrative expertise to identify procedures and requirements needed to implement binational research.

\section{Conclusion}

Binational projects are complex and require a political, administrative, bureaucratic, cultural, and language balance. Very few institutions working along the U.S.-Mexico border with a binational scope can provide guidance and support in carrying out this type of study or project. Staff working on border and binational issues must have the expertise and skill to work in a bicultural and binational environment in order to overcome binational barriers and achieve results faster because they must understand administrative, legal, technical, and ethical issues involved in such projects. We recommend that implementation of border and binational projects be coordinated by a binational organization; if that is not possible, a binational organization must be involved in the process.

\section{Recommendations}

- Implementation of any border or binational project should be done with the 
participation of binational organizations and staff that are binational and bicultural and knowledgeable about the process in both countries.

- A binational steering committee with equal representation must be appointed in order to provide technical, administrative, and expertise guidance.

- If the study or project is implemented along the U.S.-Mexico border, all communication processes pertaining to development and implementation must be done in English and Spanish to prevent misunderstandings, conflicts, and frustration.

- Definitions of each health problem to be addressed during the research must be described and clarified before the work begins. Once the differences are identified, a common definition must be agreed on by consensus in order to carry out the research.

- All administrative, legal, and financial procedures related to implementation of the study or project must be identified and documented before beginning the project in order to prevent delays.

- The capacity of both sides must be strengthened in order to implement the research under similar circumstances and facilitate the process to provide comparable results.

Acknowledgments. This survey was carried out under support of the CDC; the Mexican ministry of health; the Departments of Health of Arizona, Baja California, California, Chihuahua, Coahuila, New Mexico, Nuevo Leon, Sonora, Tamaulipas, and Texas; the California Endowment; the Paso del Norte Health Foundation; Primus Corp.; and the U.S.-Mexico Border Health Association. We express our appreciation to our CDC partners Rita Diaz-Kenney, Gloria Beckles, and Rodolfo Rodríguez for their support and commitments toward improving the health of the border population. Special thanks to Alfonso Ruiz, former chief of the U.S.-Mexico Border Field Office of PAHO. Our gratitude to Nahum Apodaca for his support in reviewing the manuscript.

\section{REFERENCES}

1. Diaz-Kenney RV, Ruiz-Holguín R, de Cosío FG, Ramos R, Rodríguez B, Beckles GL, et al. A historical overview of the United StatesMexico Border Diabetes Prevention and Control Project. Rev Panam Salud Publica. 2010; 28(3):143-50.

2. Homedes N, Ugalde A. Globalization and health at the United States-Mexico border. Am J Public Health. 2003;93(12):2016-22.

3. Castrucci B, Delgado E, Fonseca V, Dutton RJ, Berrahou F. Lessons learned from a binational survey to examine women's health status in the US-Mexico border region. Prev Chronic Dis. 2008;5(4). Available from: http://www. cdc. gov/pcd/issues/2008/oct/08_0073.htm. Accessed 23 August 2010.
4. Pan American Health Organization. Basic health indicators 2003. El Paso, TX: PAHO; 2003. Available from: http://www.infofron tera. org/lildbi/docsonline/fep002612. Accessed 23 August 2010

5. United States-Mexico Border Health Commission. Healthy Border 2010: an agenda for improving health on the United States-Mexico border. El Paso, TX: U.S.-Mexico Border Health Commission; 2010. Available from: http://www.borderhealth.org/files/res_63. pdf. Accessed 23 August 2010

6. Texas Department of Health. Barriers to binational cooperation in public health between Texas and Mexico. Senate Bill 1857. Texas 76th Legislature. 15 January 2001. Available from: http://www.dshs.state.tx.us/border health/pdf/barriers.pdf. Accessed 23 August 2010.

7. Pan American Health Organization. Final report of the phase I of the US-MX Binational Diabetes Project. El Paso, TX: PAHO; 2010.

8. Pan American Health Organization. U.S.Mexico Diabetes Project operational manual. El Paso, TX; PAHO; 2001. Available from: http:// new.paho.org/fep/images/stories/ FEP/PDF_Documents/diabetes_operations_manual.pdf. Accessed 23 August 2010.

Manuscript received on 19 April 2010. Revised version accepted for publication on 24 August 2010.
RESUMEN

\section{Encuesta de prevalencia de} diabetes en la zona fronteriza entre México y los Estados Unidos: lecciones aprendidas de la ejecución del proyecto

Palabras clave
En este artículo se analizan los principales procedimientos y normas que se deberían seguir al diseñar y ejecutar una encuesta binacional, como el estudio de prevalencia de la diabetes en la zona fronteriza entre México y los Estados Unidos que se llevó a cabo entre el 2001 y el 2002. El objetivo principal de la encuesta fue determinar la prevalencia de diabetes en las personas de 18 años o mayores en los condados y municipios fronterizos entre México y los Estados Unidos. Se definieron diversos aspectos políticos, administrativos, financieros, legales y culturales como factores fundamentales que se deben tener en cuenta al elaborar y ejecutar proyectos binacionales similares. La falta de comprensión de las prácticas de salud pública, la ejecución de las normas existentes, la legislación y los procedimientos de gestión en México y los Estados Unidos pueden retardar o cancelar las actividades de investigación binacional, y afectar las relaciones de trabajo entre ambos países. Se señalaron muchas dificultades con respecto a la multiplicidad de organismos y fuentes de financiación, las autorizaciones de carácter ético y presupuestario, la gestión del proyecto, los procedimientos administrativos, los procedimientos de laboratorio, los aspectos culturales y la comunicación del proyecto. Los proyectos binacionales son complejos; requieren coordinación entre los organismos y las instituciones a escalas federal, estatal, local y entre países, y precisan un equilibrio político, administrativo, burocrático, cultural e idiomático. El personal y los organismos binacionales deben coordinar estos proyectos con objeto de lograr su eficaz ejecución.

Salud fronteriza; cooperación internacional; diabetes mellitus; hispanoamericanos; Estados Unidos; México. 